\title{
Corporate social responsibility and governance
}

\author{
Jean-Michel Sahut ${ }^{1} \cdot$ Marta Peris-Ortiz $^{2} \cdot$ Frédéric Teulon $^{3}$ \\ Published online: 26 June 2019 \\ ๑) Springer Science+Business Media, LLC, part of Springer Nature 2019, corrected publication 2019
}

\section{Introduction}

Corporate governance (CG) and corporate social responsibility (CSR) have been important research issues for decades. The relationship between CG and CSR has been studied in financial literature in conjunction with the relationship between CSR, risk and corporate financial performance (CFP). In numerous previous studies, CG has been analysed as a pre-requisit or a component of CSR (Jamali et al. 2008; Roshima et al. 2009; García-Sánchez et al. 2015). A considerable number of these studies examining the interrelations among CSR, CFP and risk report conflicting evidence (Becchetti and Ciciretti 2009). The multiplicity of data sources and methodologies used in existing studies can explain, to a large extent, these differences in empirical results. Moreover, the relationships between CSR, governance, financial structure, and financial performance are complex, requiring more global models to better understand them (Flammer 2015).

Other fields of management literature have attempted to explain the relationship between governance and CSR engagement, policy and strategy (Carroll 1999; Danvila del Valle et al. 2013; Zingales et al. 2016). These have offered some definitions and typologies of strategic CSR behaviours in terms of corporate governance, and have demonstrated how management practices and the company's structure of CSR strategies depend on governance factors. In particular, board composition and ownership structure may explain strategic CSR decision-making and risk-taking. They shape their companies' CSR policies with the aim of hedging against potential risks including egregious unethical behaviour and outright misconduct.

An in-depth examination of CSR and governance issues is particularly important, given the alarming increase both in frequency and severity of incidents of corporate fraud. The scandals associated with Enron, WorldCom and Lehman Brothers, as well as the Ponzi schemes of Allen Stanford, Bernard Madoff and others, have

Jean-Michel Sahut

jmsahut@gmail.com

1 IDRAC Business School, Lyon, France

2 Universitat Politècnica de València, València, Spain

3 IPAG Business School, Paris, France 
undermined the confidence of investors and the public alike. Remarkably, Dyck, Morse and Zingales (2014) estimate that only 1 in 4 frauds committed are detected in the U.S. market, and that around $15 \%$ of U.S. companies were engaged in corporate fraud over the period between 1996-2004. This is particularly troublesome for those who believe that the U.S. has the highest standards of monitoring and investor protection practices worldwide. Equally disturbing is their finding that the annual cost of fraud among large U.S. companies is around $\$ 380$ billion. These results are particularly disconcerting for markets with weaker regulatory environments compared to the U.S.

Moreover, according to Gangi and Trotta (2015), socially-responsible investment funds demonstrate greater stability in their benefits in times of economic crisis than those funds whose sole aim is profit. It seems that the moral and economic values linked to CSR provide balance and robustness to the system, as well as temper the incentive to maximize profits as the sole objective.

\section{Definition of concepts: CSR and governance}

A Green Paper released by the European Commission defines Corporate Social Responsibility (CSR) as actions which allow companies to not only meet their legal obligations but also to go beyond and invest in human capital, in the environment, and in strengthening relations with stakeholders. In the spirit of the OECD, the Green Paper defines corporate governance as the system or interface which manages and controls relations between the management, the board of directors, shareholders and other stakeholders. The standard approach of "corporate governance" was initially based on the objective of optimizing company value; i.e., aligning the interests of managers and shareholders at the lowest possible cost (Turnbull 2015).

For these two concepts, the notion of stakeholder is central, although its scope is more restrictive in the case of governance, which explains the reason why the relationship between quality of governance and CSR is mainly addressed in the scientific literature in light of potential conflicts of interest between different stakeholders (Aguilera and Cuervo-Cazurra 2009; Ntim et al. 2012). Waddock and Graves (1997) argue that governance has struck a balance between economic and social interests, as well as between individual and collective interests. It is by encompassing all stakeholders, instead of only taking into account the interests of shareholders as suggested in the agency theory of Jensen and Meckling (1976), that many governance researchers have shifted their attentions to CSR issues. Corporate governance is thereafter studied in light of different ownership structures and governance practices, mainly related to the board of directors. In particular, presenting their resource dependency theory, Pfeffer and Salancik (1978) have analyzed the link between the attributes of boards of directors and their companies' CSR performance (Hillman and Dalziel 2003; Jo and Harjoto 2011).

Using a sample of S\&P500 firms, Tsoutsoura (2004) has shown that when board members own a substantial number of shares, firms are more sensitive to CSR practices. For Barnea and Rubin (2010), it is rather CEOs and senior managers who tend to over-invest in CSR activities to establish their own personal reputation as good 
citizens, which can lead to conflicts with other stakeholders. In the same perspective, Ntim and Soobaroyen (2013) highlight that in well-governed firms, managers develop more CSR practices. Their results indicate that board size, diversity, and the number of independent directors significantly affect the adoption of CSR practices. Overall, prior literature has shown that certain characteristics of board of directors, including board composition and functioning, play a monitoring role aimed at ensuring a balance between the interests of the different stakeholders, which explains to a large extent CSR practices (Hillman and Dalziel 2003; Mallin et al. 2013).

\section{Differences between CSR and ethics}

Business ethics and CSR are closely related. Two schools of thought argue that CSR policies are highly effective and that their objectives reach beyond the sole purpose of communication. The first of these proposes to limit the scope to the notion of business ethics, according to the Anglo-Saxon perspective, and contrast this with corporate responsibility approaches rooted in social objectives, a more European stance, rather than moral principles (Maxim 2014). The second model argues a mixture of ethics and CSR (Postel and Rousseau 2008). From a practical point of view, these two schools of thought are closely related, because a socially-responsible company with a CSR policy should be an ethical company, and an ethical company should be socially responsible (Fassin et al. 2011).

For most companies, the scope of accountability and ethics are limited to legal obligations and sometimes to codes of best practices, while profitability remains the only criterion that affects company decisions. However, ethical codes are becoming increasingly popular, especially in large companies, and cover areas such as CSR, quality of customer relationships and supply chains, respect for the environment, and personal and corporate integrity charters. In this approach, assessing the ethical performance of a company includes CSR as a dimension of ethics.

\section{The dimensions of CSR strategies}

CSR considers that company responsibility should be shared beyond the owners alone, instead extending to the various stakeholders. Responsiveness to pressures from stakeholders depends on the environmental and social risks companies take. The power, legitimacy and urgency of stakeholder demands shape managerial decisions with regards environmental and social concerns (Mitchell et al. 1997).

The most studied CSR dimension is by far governance, which creates consensus among studies (Orlitzky 2013). The second most studied dimension is the environment. However, social factors are much less studied. Horváthová's (2010) metaanalysis of ecological studies warns that simple correlation coefficients generate more negative results when linking performance to ecological factors. Therefore, it seems appropriate to rely more on advanced econometric methods instead. She also 
highlights that a positive link is found more frequently in common law countries than in civil law countries, which brings us to our next topic.

Concerning the country of observation, there seems to be a difference in empirical results obtained in the U.S. compared to other countries. Studies on the U.S. context more often find positive results, while studies on non-U.S. companies tend to lead to more neutral results. An attempt to justify these discrepancies can be found in the activism of U.S. pension funds toward sustainability.

\section{The relationship between corporate governance, CSR and corporate financial performance}

This section presents a literature review related to the relationships between corporate governance (CG), corporate social responsibility (CSR) and corporate financial performance (CFP). The relationship between CSR and CG has been widely discussed in recent research in reference to problems with conflicts between various stakeholder interests (Aguilera et al. 2007; Ntim et al. 2012; Starks 2009; Shahzad et al. 2016). A large part of the literature defends the idea that the adoption of CSR policies leads to the implementation of new regulations standards and better CG mechanisms within a company (Albareda et al. 2008). The results of previous studies remain inconclusive and at the very least require further research.

The adoption of CSR principles should not be perceived as the simple consequence of a marginal decision made within the company. Instead, adopting these principles is part of the company's wider culture and all of its hierarchical components are involved. The decision to adopt these principles is made at the top, and stakeholders need to ensure that managers apply CSR principles in accordance with these decisions to optimize the development of appropriate internal CG mechanisms to reflect this.

These CG mechanisms promoting CSR emerged in the aftermath of infamous accounting scandals such as Enron, HealthSouth, Tyco, and Worldcom, all of which have shaken the trust of investors (Agrawal and Chadha 2005). The aim of promoting CSR was to reestablish investors' confidence in the financial system. Companies are now required to be more transparent and to provide more timely and intelligible disclosure regarding financial statements and corporate governance practices. Disclosure of information by the management team responsible implementing CSR activities has become increasingly commonplace.

In the same context, the standard governance approach was based on the basic objective of optimizing company value. In other words, the objective of good governance is to align the interests of stakeholders and managers at a low cost to the company (Turnbull 2015). Waddock and Graves (1997) argue that CG develops a balance between economic and social objectives, as well as between individual and community goals. Based on a large sample of companies from the S\&P 500, Tsoutsoura (2004) finds that, when board members own a large portion of stocks, companies are more sensitive to CSR practices.

In light of this review, we hypothesize the existence of a significant relationship between CG and CSR. This argument was also put forward by Kendall (1999), who 
supports the idea that good governance preserves stakeholder interests related to CSR policy. Ntim and Soobaroyen (2013) confirm the results presented by Aguilera et al. (2007) and find evidence that, in well-governed companies (i.e. those promoting high levels of accountability, responsibility, and transparency), managers are more likely to implement positive CSR practices. To summarize, the literature suggests that well-governed companies are more likely to adopt CSR practices.

Many studies have examined the relationship between company-specific characteristics and their CSR practices in order to identify their financial and non-financial determinants. For the financial determinants, the research is mainly based on slackresource theory, which suggests that better financial performance results in more available resources which may be allocated to CSR activities (Waddock and Graves 1997). We argue that this relationship will also be mediated by the company's size, intangibles, and leverage. Using different methodological approaches, Adams et al. (1998), Neu et al. (1998), Brammer and Pavelin (2006), and Haniffa and Cooke (2005) find that the extent of corporate social disclosure is positively related to the size of the company. Thus, large companies are expected to have a high level of systematic risk and therefore to counter this by placing greater emphasis on the long term than smaller companies. Therefore, companies will disclose corporate social information to both reduce risk and reassure investors.

Intangible assets also play a role. For Surroca et al. (2010), intangible assets moderate the relationship between corporate social performance and CFP, in both directions. Intangibles such as reputation, trust, and capacity to innovate, all widely recognized as being fundamental to strong financial performance, are at the same time integral to the CSR agenda (Brondoni 2010). Thus, an intimate link exists between intangibles and CSR, and we can suppose that investments in intangibles increase with the level of CSR practices.

Among studies interested in the impact of the financial structure on the adoption of CSR rules, Purushothaman et al. (2000) find that high-leverage companies have closer relationships with their creditors and use other means to disclose social responsibility information. Brammer and Millington (2008) argue that a high level of leverage negatively affects the reputation of the company. Therefore, the company should implement CSR practices to improve its image on the stock market. However, Zweibel (1996) demonstrates how excessive company debt increases interest expenses, discouraging investment in CSR. Thus, compliance with shareholder profitability goals is often in conflict with the cost involved in setting up CSR practices. For this reason, the capacity of a company to invest in CSR practices is expected to depend on its economic performance. As a result, financial resources allocated to CSR activities are simply generated by current operations, which can be measured by the operating income. The main advantage of this financial indicator is that it does not take the financial structure and taxes into account (Ernst \& Young's Corporate Responsibility Report 2012).

While the determinants of a company's social responsibility have been the subject of numerous studies, the main focus has been on testing the impact of CSR practices on company performance. Several researchers have found a negative relationship between CSR and CFP (e.g. McGuire et al. 1988; Preston and O'Bannon 1997). These authors argue that companies engaged in CSR strategies 
face additional costs which negatively affect their performance. Other empirical studies have found that CSR does not affect CFP (Aragón-Correa and RubioLópez 2007; Chand and Fraser 2006; Mahoney and Roberts 2007; McWilliams and Siegel 2000, 2001). Based on different company samples, these studies do not support any particular relationship between CSR and corporate financial performance. A third group of researchers found a positive relationship between CSR activities and financial performance (accounting and stock market performance measures). They argue that the costs of CSR are minimal, and that the benefits are potentially consequential. Orlitzky (2013) identified a positive relationship between CSR and CFP and argued that CSR enhances a company's reputation. In addition, they suggest that CSR raises managerial skills and improves the organizational efficiency of the company. Margolis et al. (2009) provide a metaanalysis of 251 studies for the period between 1972 and 2007 which investigate the link between CSR and CFP. These authors show that the majority of studies provide evidence of a significant positive relationship between the adoption of CSR principles and the accounting performance of a given company. Focusing on the same issue, Tsoutsoura (2004) found a significant and positive impact of CSR on a company's return on equity (ROE) and ROA. She supports the view that socially responsible corporate performance can be associated with a series of bottom-line benefits. These results furthermore corroborate the findings of previous studies conducted in different markets, such as Russo and Fouts (1997), Nakao et al. (2007), Scholtens (2008), Brammer and Millington (2008), Okamoto (2009), and Yang et al. (2010). The slack-resource theory suggests that this relationship is reversible and can create a synergetic circle. One main determinant of CSR politics is the availability of financial resources, and that companies able to invest in CSR are expected to perform better (Waddock and Graves 1997). However, different studies have established that a company's capacity to invest in CSR depends more on size, leverage, and other investments in intangibles than on their financial performance (Surroca et al. 2010). Thus, these resources, financial and otherwise, are necessary to improve social performance.

On the other hand, several studies have found evidence of a significant relationship between CSR and stock market performance. In this context, Navarro (1988) and Webb (1996) suggest that CSR practices increase the transactional volume of shares as well as the share price, up to a certain threshold. Moreover, Dowell et al. (2000), in a study of the impact of CSR disclosure on company performance, show that a high level of CSR reporting positively affects a company's market performance as measured by Tobin's Q.

The lack of consistency in these empirical results may be explained by two factors. Firstly, the relationships between CG, CSR and financial performance are partially explored in pairs, therefore these factors may also operate in reverse and create a synergetic circle, yet they are not examined as a whole (Waddock and Graves 1997). However, these relationships are more complex, and a more global model is required to better understand them (Flammer 2015). Secondly, the multiplicity of data and methodologies used can explain the inconsistent empirical results observed. Specifically, a problem of endogeneity exists between CSR and CFP variables, and the strength of the link between financial and CSR performances depends 
on the way they are measured, as well as numerous moderating variables (Orlitzky 2013; Gramlich and Finster 2013).

Based on the above-mentioned discussion, the debate on the causal effect of CSR practices on financial performance is still open and new approaches are necessary. Moreover, the lack of a clear consensus on this relationship suggests that only a particular combination of environmental, social, and societal practices are likely to influence corporate financial performance. These particular practices are highly dependent on the availability of financial resources discretionarily allocated to meet stakeholders' interests, as well as on the power balance between different stakeholders.

The objective of this special issue is to understand the intertwined links between CG, financial variables, CSR, and CFP based on comprehensive empirical models which take into account interactions between these different factors as the theory suggests. Thus, it aims to investigate the extent to which a company's internal CG structures and financial variables may influence CSR practices and the impact of these practices on the market and accounting performances of the company.

\section{The content of this special issue}

This special issue of the Journal of Management and Governance brings together research from authors in France, Switzerland, the United Kingdom, Tunisia, and further afield. The underlying theme of the articles is the nature of corporate social responsibility and its relationships with governance, financial structure and financial performance.

The special issue begins with a study by Maria Giuseppina Bruna, Rey Dang, Marie-José Scotto, and Aymen Ammari addressing the question "Does board gender diversity affect firm risk-taking? Evidence from the French stock market". Drawing on a sample of French companies listed on the SBF120 index over the 2006-2010 period, the authors find no evidence of any significant relationship between the proportion of women on corporate boards and corporate risk-taking practices. This result brings into question the usefulness of the Copé-Zimmermann law on gender quotas on management boards enacted in January 2011 and which took effect from early 2017, obliging French companies to include at least $40 \%$ of women on their boards. The results are also consistent with Nelson (2015) who considers that men and women do not behave significantly differently in terms of risk-taking.

The second paper of the special issue, by Fatma Baalouch, Salma Damak Ayadi and Khaled Hussainey is "A study of the determinants of environmental disclosure quality: Evidence from French listed companies". This paper combines several theories in a unique framework, to assess the factors which shape the quality of environmental disclosure. In particular, the paper looks at the effects of a company's environmental strategy (Environmental audit, presence of an environmental committee, environmental performance, and the company's carbon footprint) and board diversity (board independence and gender diversity) on the disclosure of environmental information. In the footsteps of Chauvey et al. (2015), the authors develop an index based on recommendations by the IASB, FASB and 
GRI to gauge the quality and extent of environmental disclosure. Using a sample of French companies listed on the SBF120 index over the 2009-2014 period, the authors show that quality of environmental disclosure is relatively low in France but tends to increase over the sample period. They also show that environmental audit, board gender diversity and environmental performance explain, to a large extent, the quality of environmental disclosure.

Mehdi Mili, Sami Gharbi, and Frédéric Teulon focus on "Business Ethics, firm value \& Ownership" in the third paper of the special issue. Specifically, they test the impact of ethical performance on company value and the attractiveness of stocks for main shareholders (i.e., large owners, institutional investors and insiders). The authors use the Ethisphere ${ }^{\circledR}$ database to disentangle ethical companies from others and to show that best ethical practices improve company value in the US. This result is consistent with prior literature suggesting that companies are able to create value for all stakeholders. Moreover, the authors provide evidence that institutional investors are more likely to invest in ethical companies as they play an effective monitoring role in encouraging these companies to strengthen their ethical behavior.

The fourth paper by Rihem Braham, Christian de Peretti, and Lotfi Belkacem is entitled "Do political connections affect bank leverage? Evidence from some Middle Eastern and North African countries". The authors use a sample of commercial banks from the MENA region for the period between 2003 and 2014 to study whether political patronage shapes banks' financing decisions. The authors demonstrate how politically-connected banks are more likely to exhibit high levels of leverage. This effect is found to be larger among highly-profitable banks, suggesting that privileged relations with politicians help banks to be more profitable and lead to higher levels of leverage. Politicians on boards of directors seem to be a valuable resource and to play an important role in shaping banks' financing decisions. Depositors may perceive politically-connected banks as being less risky, as they are more inclined to be bailed out by the government when facing financial difficulties.

The final paper, written by Eric Braune, Pablo Charosky and Lubica Hikkerova, is "Corporate social responsibility, financial performance, and risk in times of economic instability". This paper analyzes the effect of a company's social responsibility on stock market returns from a systematic risk angle. The authors begin by looking at the link between CSR and systematic company risk, then investigate the relationship between CSR and company performance. The empirical evidence indicates a negative relationship between corporate social performance and systematic risk, leading to higher stock returns for those companies which implement socially responsible strategies. These strategies are considered by investors to be insurance against the negative effects of periods of turmoil.

We would like to thank Lino Cinquini, editor-in-chief of the Journal of Management and Governance, for offering me the opportunity to guest-edit this special issue. Our sincere thanks also to all the reviewers for the time and effort they invested in providing feedback on these papers. And, last but not least, our thanks to the contributing authors for their intellectual contributions and for the quality of their work, including during the reviewing process. All views expressed in the papers remain, of course, the sole responsibility of the contributing authors. 


\section{References}

Adams, C. A., Hill, W. Y., \& Roberts, C. B. (1998). Corporate social reporting practices in western Europe: Legitimating corporate behavior? The British Accounting Review, 30(1), 1-21.

Agrawal, A., \& Chadha, S. (2005). Corporate governance and accounting scandals. Journal of Law and Economics, 48, 371-406.

Aguilera, R. V., \& Cuervo-Cazurra, A. (2009). Codes of good governance. Corporate governance: An international review, 17(3), 376-387.

Aguilera, R., Rupp, D., Williams, C., \& Ganapathi, J. (2007). Putting the S back in corporate social responsibility: A multilevel theory of social change in organizations. The Academy of Management Review, 32(3), 836-863.

Albareda, L., Lozano, J., Tencati, A., Midttun, A., \& Perrini, F. (2008). The changing role of governments in corporate social responsibility: drivers and responses. Business ethics: A European review, 17(4), 347-363.

Aragón-Correa, J. A., \& Rubio-López, E. A. (2007). Proactive corporate environmental strategies: Myths and misunderstandings. Long Range Planning, 40(3), 357-381.

Barnea, A., \& Rubin, A. (2010). Corporate social responsibility as a conflict between shareholders. Journal of Business Ethics, 97(1), 71-86.

Becchetti, L., \& Ciciretti, R. (2009). Corporate social responsibility and stock market performance. Applied Financial Economics, 19, 1283-1293.

Brammer, S., \& Millington, A. (2008). Does it pay to be different? An analysis of the relationship between corporate social and financial performance. Strategic Management Journal, 29(12), 1325-1343.

Brammer, S., \& Pavelin, S. (2006). Voluntary environmental disclosure by large UK companies. Journal of Business Finance and Accounting, 33(7-8), 1168-1188.

Brondoni, S. M. (2010). Intangibles, global networks \& corporate social responsibility Symphonya. Emerging Issues in Management, 2, 6-26.

Carroll, A. B. (1999). Corporate social responsibility. Business and Society, 38(3), 268-295.

Chand, M., \& Fraser, S. (2006). The relationship between corporate social performance and corporate financial performance. The Business Review, 5(1), 240-245.

Chauvey, J. N., Giordano-Spring, S., Cho, C. H., \& Patten, D. M. (2015). The normativity and legitimacy of CSR disclosure: Evidence from France. Journal of Business Ethics, 130(4), 789-803.

Danvila del Valle, I., Diez Esteban, J.M., Péres, \& Lopez de Foronda, O. (2013). Corporate social responsibility and sustainability committee inside the boar. Available at SSRN: https://ssrn.com/abstr act $=2260382$. Accessed 28 Mar 2019.

Dowell, G., Hart, S., \& Yeung, B. (2000). Do corporate global environmental standards create or destroy market value? Management Science, 46(8), 1059-1074.

Dyck, A., Morse,A., \& Zingales, L. (2014). How pervasive is corporate fraud? University of Chicago, Working paper.

Ernst \& Young (2012). Ernst \& Young's Corporate Responsibility Report. Retrieved from https://www. ey.com/Publication/vwLUAssets/CSR-Ukraine-FY2012-Eng/\$FILE/CSR-Ukraine-FY2012-Eng. pdf.

Fassin, Y., Van Rossem, A., \& Buelens, M. (2011). Small-business owner-managers' perceptions of business ethics and CSR-related concepts. Journal of Business Ethics, 98(3), 425-453.

Flammer, C. (2015). Does corporate social responsibility lead to superior financial performance? $A$ Regression Discontinuity Approach. Management Science, 61(11), 2549-2568.

Gangi, F., \& Trotta, C. (2015). The ethical finance as a response to the financial crises: An empirical survey of European SRFs performance. Journal of Management and Governance, 19(2), 371-394.

García-Sánchez, I.-M., Rodriguez-Dominguez, L., \& Frías-Aceituno, J.-V. (2015). Board of Directors and ethics codes in different corporate governance systems. Journal of Business Ethics, 131, 681-698.

Gramlich, D., \& Finster, N. (2013). Corporate sustainability and risk. Journal of Business Economics, 83, 631-664.

Haniffa, R. M., \& Cooke, T. E. (2005). The impact of culture and governance on corporate social reporting. Journal of Accounting and Public Policy, 24(5), 391-430.

Hillman, A. J., \& Dalziel, T. (2003). Boards of directors and firm performance: Integrating agency and resource dependence perspectives. Academy of Management Review, 28(3), 383-396. 
Horváthová, E. (2010). Does environmental performance affect financial performance? A meta-analysis. Ecological Economics, 70(1), 52-59.

Jamali, D., Safieddine, A. M., \& Rabbath, M. (2008). Corporate governance and corporate social responsibility synergies and interrelationships. Corporate Governance: An International Review, 16(5), 443-459.

Jensen, M. C., \& Meckling, W. H. (1976). Theory of the firm: Managerial behavior, agency costs and ownership structure. Journal of Financial Economics, 3(4), 305-360.

Jo, H., \& Harjoto, M. A. (2011). Corporate governance and firm value: The impact of corporate social responsibility. Journal of Business Ethics, 103(3), 351-383.

Kendall, N. (1999). Good corporate governance, accountants' digest. Issue 40. The ICA in England and Wales.

Mahoney, L., \& Roberts, R. W. (2007). Corporate social performance, financial performance and institutional ownership in Canadian firms. Accounting Forum, 31, 233-253.

Mallin, C., Michelon, G., \& Raggi, D. (2013). Monitoring intensity and stakeholders' orientation: How does governance affect social and environmental disclosure. Journal of Business Ethics, 114(1), 29-43.

Margolis, J., Elfenbein, H., \& Walsh, J. (2009). Does it pay to be good? A meta-analysis and redirection of research on the relationship between corporate social and financial performance, Working Paper Harvard University, Available at SSRN: http://ssrn.com/abstract=1866371. Accessed 28 Mar 2019.

Maxim, S. T. (2014). Ethics: Philosophy or science? Procedia-Social and Behavioral Sciences, 149, $553-557$.

McGuire, J. B., Sundgren, A., \& Schneeweis, T. (1988). Corporate social responsibility and firm financial performance. Academy of Management Journal, 31(4), 854-872.

McWilliams, A., \& Siegel, D. (2000). Corporate social responsibility and financial performance: Correlation or misspecification? Strategic Management Journal, 21(5), 603-609.

McWilliams, A., \& Siegel, D. (2001). Corporate social responsibility: A theory of the firm perspective. Academy of Management Review, 26(1), 117-127.

Mitchell, R. K., Agle, B. R., \& Wood, D. J. (1997). Toward a theory of stakeholder identification and salience: Defining the principle of who or what really counts. Academy of Management Review, 22(4), 853-886.

Nakao, Y., Amano, A., Matsumura, K., Genba, K., \& Nakano, M. (2007). Relationship between environmental performance and financial performance: an empirical analysis of japanese corporations. Business Strategy and the Environment, 16(2), 106-118.

Navarro, P. (1988). Why do corporations give to charity? Journal of Business, 61(1), 65-93.

Nelson, J. A. (2015). Are women really more risk-averse than men? A re-analysis of the literature using expanded methods. Journal of Economic Surveys, 29, 566-585.

Neu, D., Warsame, H., \& Pedwell, K. (1998). Managing public impressions: Environmental disclosures in annual reports. Accounting, Organizations and Society, 23(3), 265-282.

Ntim, C. G., Opong, K. K., \& Danbolt, J. (2012). The relative value relevance of shareholder versus stakeholder corporate governance disclosure policy reforms in South Africa. Corporate Governance: An International Review, 20(1), 84-105.

Ntim, C. G., \& Soobaroyen, T. (2013). Black economic empowerment disclosures by South African listed corporations: The influence of ownership and board characteristics. Journal of Business Ethics, 116(1), 121-138.

Okamoto, D. (2009). Social relationship of a firm and the CSP-CFP relationship in Japan: Using artificial neural networks. Journal of Business Ethics, 87(1), 117-132.

Orlitzky, M. (2013). Corporate Social Responsibility, Noise, and Stock Market Volatility. Academy of Management Perspectives, 27(3), 238-254.

Pfeffer, J., \& Salancik, G. R. (1978). The external control of organizations: A resource dependence perspective. New York: Harper and Row.

Postel, N., \& Rousseau, S. (2008). RSE et éthique d'entreprise : la nécessité des institutions. Management, 11(2), 137-160.

Preston, L. E., \& O'Bannon, D. P. (1997). The corporate social-financial performance relationship: A typology and analysis. Business and Society, 36, 419-429.

Purushothaman, M. G., Hancock, T. R., \& Taplin, R. (2000). Determinants of corporate social reporting practices of listed Singapore companies. Pacific Accounting Review, 12(2), 101-133. 
Roshima, S., Zainuddin, Y. H., \& Haron, H. (2009). The relationship between corporate social responsibility disclosure and corporate governance characteristics in Malaysian public listed companies. Social Responsibility Journal, 5(2), 212-226.

Russo, M. V., \& Fouts, P. A. (1997). A resource-based perspective on corporate environmental performance and profitability. Academy of Management Journal, 10(3), 534-559.

Scholtens, B. (2008). A note on the interaction between corporate social responsibility and financial performance. Ecological Economics, 68(1-2), 46-55.

Shahzad, A. M., Mousa, F. T., \& Sharfman, M. P. (2016). The implications of slack heterogeneity for the slack-resources and corporate social performance relationship. Journal of Business Research, 69(12), 5964-5971.

Starks, L. T. (2009). Corporate governance and corporate social responsibility: What do investors care about? What should investors care about? Financial Review, 44, 461-468.

Surroca, J., Tribo, J. A., \& Waddock, S. (2010). Corporate responsibility and financial performance: The role of intangible resources. Strategic Management Journal, 31(5), 463-490.

Tsoutsoura, M. (2004). Corporate social responsibility and financial performance. University of California, Berkeley, Working Paper, March.

Turnbull, S. (2015). Defining and achieving good governance. Available at SSRN: http://ssrn.com/abstr act $=2571724$. Accessed 28 Mar 2019.

Waddock, S. A., \& Graves, S. B. (1997). The corporate social performance-financial performance link. Strategic Management Journal, 18, 303-319.

Webb, N. J. (1996). Corporate profits and social responsibility: Subsidization of corporate income under charitable. Journal of Economics \& Business, 48, 401-421.

Yang, F. J., Lin, C. W., \& Chang, Y. N. (2010). The linkage between corporate social performance and corporate financial performance. African Journal of Business Management, 4(4), 406-413.

Zingales, L., Guiso, L., \& Sapienza, P. (2016). The values of corporate culture. Journal of Financial Economics, 117(1), 60-76.

Zweibel, J. (1996). Dynamic capital structure under managerial entrenchment. American Economic Review, 86, 1197-1215.

Publisher's Note Springer Nature remains neutral with regard to jurisdictional claims in published maps and institutional affiliations.

Jean-Michel Sahut, Ph.D., is a Professor at IDRAC Business School Lyon (Fr). He teaches Corporate Finance, Entrepreneurial Finance, Entrepreneurship, Innovation \& TIC and Serious Game for engineering and management students. Previously, he was Professor at Geneva School of Business Administration, University of Applied Sciences (Ch), Associate Dean for Research at Amiens School of Management (Fr), Professor of Finance at Telecom \& Management Paris Sud (Fr) and the director of the RESFIN Laboratory. He has published more than 90 articles about finance, influence of information technology, and entrepreneurship in international peer review journals and five books. He has already been guest editor of Small Business Economics, Economic Modelling, and Technological Forecasting and Social Change. He is the editor-in-chief of Gestion 2000 (ranked by Fnege).

Marta Peris-Ortiz is Professor at Universitat Politecnica de Valencia (Polytechnic University of Valencia). Her current research is focused on the topics of Entrepreneurship, Corporate Social Responsibility, Sustainability, Innovation, Knowledge Management and Education Innovation. She has published articles in journals such as Journal Business Research, Management Decision, Service Industries Journal, Technological Forecasting and Social Change, Service Business, European Journal of International Management, Journal of International Change Management... She has also been Editor of several books published by Springer such as New Challenges in Entrepreneurship and Finance.

Frédéric Teulon is the Executive Head of Research and Dean of the Faculty at IPAG Business School. He hold an "agrégation" of Economics and Social Science. He is a former student of the ENS Paris-Saclay (Ecole Normale Supérieure), of IEP Paris (Institut d'Etudes Politiques) and of Paris 1 Panthéon-Sorbonne University. He founded in 2008 the IPAG Lab (a research laboratory in economics and management). He co-founded three international conferences: IRMBAM (International Research Meeting in Business \& 
Management), ISEFI (International Symposium on Environment \& Energy Finance Issues), PFMC (Paris Financial Management Conference). He has published over 40 books and over 40 peer-reviewed journal articles on macroeconomics, finance, and management (in journals such as Revue Economique, Management International, Economic Modelling...). 